\title{
STATUS WANITA CERAI DAN GUGAT CERAI: STUDI KASUS DI PENGADILAN AGAMA JAKARTA BARAT TAHUN 2014-2015
}

\section{Fitri Mustafa}

STAI Nurul Iman Parung Bogor

Email : fitristaini@gmail.com

\begin{abstract}
ABSTRAK
Produk pemikiran hukum Islam di Indonesia terdiri dari produk pemikiran fikih, fatwa ulama, keputusan pengadilan (yurisprudensi), dan produk pemikiran dari undang-undang. Produk-produk hukum tersebut diharapkan dapat menjawab masalah dan tantangan yang terjadi di masyarakat. Meskipun fakta dan kenyataan di lapangan tidak sama dengan asumsi umum. Terlebih mengenai pernikahan. Tepatnya masalah perceriaan. Tinggi nya angka perceriaan di Indonesia membuat sebagian kalangan mengugat kembali tentang konsep bahagia dalam rumah tangga.
\end{abstract}

Kata Kunci : Hukum Keluarga, Hak-Hak Wanita, Perceraian

\begin{abstract}
The products of Islamic legal thinking in Indonesia consist of the products of figh thought, ulama fatwa, judicial decisions (jurisprudence), and thought products from the law. These legal products are expected to be able to answer the problems and challenges that occur in the community. Although the facts and facts on the ground are not the same as general assumptions. Especially regarding marriage. Precisely the issue of happiness. The high rate of happiness in Indonesia makes some people sue again about the concept of happiness in the household.
\end{abstract}

Keyword : Family Law, Divorce, Hak-Hak Wanita 


\section{Pendahuluan}

Penggugat mayoritas didominasi oleh perempuan. ${ }^{1}$ Kesadaran gender kaum wanita muslim telah menimbulkan fenomena baru di era modern saat ini. Yakni fenomena tingkat perceraian pasangan muslim berpendidikan tinggi meningkat ${ }^{2}$. Perceraian dengan kecenderungan gugat juga lebih banyak dibanding cerai talak. Biasanya tingkat perceraian yang tinggi dialami oleh negara atau wilayah yang tingkat pendidikan masyarakatnya relatif rendah ${ }^{3}$. Fenomena yang berbalik ini tentunya telah menimbulkan masalah yang harus dihadapi, baik pasangan yang bercerai dan berbagai pihak ${ }^{4}$.

Fenomena tingginya angka perceraian ${ }^{5}$ tidak hanya terjadi di Indonesia. Tapi juga terjadi di banyak belahan dunia. Terlebih di negara mayoritas muslim. Seperti Mesir, Tunisia, Turki, Saudi Arab, dan Maroko. Begitu juga dengan negaranegara seperti Rusia, Spanyol, dan Prancis. Lexemburg negara bagian EROPA dengan angka cerai tertinggi dengan persentasi 87 persen. Rata-rata usia pernikhan di atas 21 tahun. Adapun kelompok yang paling banyak melakukan perceraian adalah 40-49 tahun. Spanyol memiliki angka perceraian cukup tinggi yaitu 66 persen. Faktor ekonomi menjadi penyebab utama. Hal sama juga terjadi di negara Prancis. Tingkat percerian di Prancis menempati urutan ketiga di dunia. Persentase 55 persen. Diteliti 1000 penduduk mengalami perceraian. Usia pernikahan di Prancis 15-18 tahun. Mereka mesti membutuhkan persetujuan setidaknya salah satu orang tua. Faktor utama disebabkan oleh pernikahan dini. Rusia juga menjadi salah satu negara dengan tingkat perceraian cukup tinggi. Penyebab utama di sebabkan oleh ketidaksetiaan, kemiskinan, alkoholisme, dan kecanduan narkoba menjadi penyebab tingkat perceraian. Penelitian menyatakan bahwa sepertiga perkawinan gagal dalam 5 tahun. ${ }^{6}$

Menurut Khofifah (2006), ketidakadilan, diskriminasi, dan kekerasan terhadap perempuan masih terjadi baik dalam ranah publik maupun domestik. Teksteks fikih yang sering kali dijadikan sebagai isntrumen atau argumen untuk menegaskan bahwa memang domain domestik merupakan khusus urusan atau tanggung jawab bagi perempuan berbeda dengan laki-laki. Faktor lain yang turut menjadikan kalangan perempuan mengalami ketidakadilan dan diskriminasi adalah aturan atau ketentuan-ketentuan dalam undang-undang tertentu yang menjelaskan bahwa batas wilayah wanita hanya bersifat domistik. Jika pun ada dalam ranah publik, ada beberapa syarat yang mesti dipenuhi oleh perempuan untuk mendapat

${ }^{1}$ Nur Azizah Hatugalung, Edi Gunawan, Taklik Talak dan Akibat Hukumnya Dalam

Kompilasi Hukum Islam Perspektif Teori Feminis, Al-Mizan: Jurnal Pemikiran Hukum Islam, Vol. 15, No.1, 2019, h. 184.

${ }^{2}$ Isnawati Rais, Tingginya Angka Cerai Gugat (Khulu') di Indonesia: Analisis Kritis Terhadap Penyebab dan Alternatif Solusi Mengatasinya, Al-‘ADALAH Vol. XII, No. 1 Juni 2014, h. 203

${ }^{3}$ Asniar Khumas, Model Penjelasan Intensi Cerai Perempuan Muslim di Sulawesi Selatan, Jurnal Psikologi: Vol. 42, No. 3, Desember 2015, h. 190

${ }^{4}$ Nunung Rodliyah, "Perceraian Pasangan Muslim Berpendidikan Tinggi (Studi Kasus di Kota Bandar Lampung” UIN Sunan Kalijaga. 2011).

${ }^{5}$ Fachrina dan Rinaldi Eka Putra, Upaya Pencegahan Perceraian Berbasis Keluarga Luas dan Institusi Lokal dalam Masyarakat Minangkabau di Sumatra Barat, Antropologi Indonesia Vol. 34, No. 2. 2013, h. 102

${ }^{6}$ Dikutip dari berbagai sumber Online https://news.detik.com/kolom/3712302/fenomena-gugat-cerai-pada-perempuan. (Fenomena gugat ceria oleh Perempuan, Nurul Latifah). http://nakita.grid.id/read/02964836/fenomena-cerai-makinmenjamur-5-negara-ini-punya-angka-perceraian-tertinggi-berikut-motifnya?page=all. $\quad$ (Fenomena Cerai Makin Menjamur, 5 Negara Ini Punya Angka Perceraian Tertinggi). 
keduduk atau posisi layaknya laki-laki. Di bagian lain, masyarakat Indonesia pada umumnya bersifat patriarkis. Seorang laki-laki memiliki sifat dominan. Sehingga aturan yang muncul merupakan refleksi dari bias dan merupakan penilaian persepktif laki-laki. Kenyataan ini, menunjukkan diskriminasi terhadap kalangan perempuan masih terus terjadi. Padahal, Ketentuan dalam udang-undang Indonesia dinyatakan bahwa kedudukan seorang laki-laki dan perempuan sama baik di mata hukum, sosial, budaya, dan ekonomi. ${ }^{7}$

Menurut Nasarudin Umar (Ketua Dewan Masjid Istiqlal, 2015), Dalam setahun ada satu juta pernikahan terjadi di Indonesia. $10 \%$ hasil pernikahan tersebut berujung pada perceraian. Pada tahun 2013. Kemenag merilis, diperkirakan, ada 2,2 juta pernikahan. Dan kejadian perceraian sekitar 324 ribu kasus. Pada tahun 2009 ada 2,1 juta pernikahan berujung 216 ribu perceriaan. Setiap tahun selalu meningkat. Dari 200 kasus menjadi 300 ribu kasus. Angka percerain di Indonesia tertinggi se ASIA. Dua fenomena percerain terjadi di Indonesia, 70\% penggugat adalah perempuan. Kedua, sebagian terjadi pada pernikahan dini atau nikah muda. Masalah percerian disebabkan oleh KDRT, ekonomi, dan perselingkuhan. Bagi Nazarudin Umar, akar masalah dari tinggi nya angka percerian di Indonesia disebabkan oleh pengadilan terlalu cepat memutus perkara di pengadilan dalam pernikahan dini dan budaya kawin siri. Semenjak PA di bawah MA. Proses ceria lebih mudah dan cepat. Upaya mencegah mediasi kedua belah pihak dikesampingkan. Hakim tentu ingin mempercepat proses di Pengadilan, jika berkas menumpuk tentu performa dinilai jelek. Pengadilan Agama perlu kerjasama dengan Kemenag. Dalam proses perceraian upaya mediasi lebih utama. Nasarudin Umar meminta kepada para ulama Indonesia agar dibuat fatwa bahwa nikah siri tidak lah sah. Dengan dalil lebih banyak mudharat nya ketimbang manfaatnya. Semua pernikahan mesti didaftarkan atau dicatat oleh admintrasi negara. Menurut ketua kongres wanita Indonesia. Giwo Rubianto Wijoyo, Pernikahan dini tidak hanya menyebabkan perceriaan melainkan juga, menyumbang lonjakkan perdagangan manusia. Penelantaran anak, dan kematian ibu. ${ }^{8}$

\section{Tinjauan Pustaka}

Tingginya angka cerai gugat tidak lepas dari makin baiknya pemahamnya kalangan perempuan terhadap hak-hak mereka sebagai istri satu sisi, di lain sisi kemandirian ekonomi juga turut menjadi alasan gugat cerai banyak terjadi. ${ }^{9}$ Meskipun di bagian yang lain, pernikahan tidak lagi dianggap suatu ibadah yang mesti dijaga dan dipertahankan karena alasan pragmatis. ${ }^{10}$ Hubungan hanya bersifat transaksional dan terjamin secara financial, ketika tujuan itu tidak tercapai, perceraian dianggap sebagai jalan terbaik.

Undang-undang keluarga Indonesia menjamin bahwa seorang istri yang dicerai berhak terhadap hak-hak nafkah, mut'ah, dan harta bersama sesuai dengan ketentuan yang berlaku ${ }^{11}$. Meskipun pada praktiknya pengadilan telah memutuskan bahwa hak nafkah dan harta yang seharusnya diterima istri pasca cerai seringkali

\footnotetext{
${ }^{7}$ Khofifah Indar Parawansa, Mengukir Paradigma Menembus Tradisi: Pemikiran Tentang Keserasian Jender. (Jakarta: LP3ES, 2006).

${ }^{8}$ Dikutip dari Harian Media Indonesi. Terbitan. 15, Desember 2015.

${ }^{9}$ Asniar Khumas, Model Penjelasan Intensi Cerai Perempuan Muslim di Sulawesi Selatan, Jurnal Psikologi: Vol. 42, No. 3, Desember 2015.

${ }^{10}$ Isnawati Rais, Tingginya Angka Cerai Gugat (Khulu') di Indonesia: Analisis Kritis Terhadap Penyebab dan Alternatif Solusi Mengatasinya, Al-‘ADALAH Vol. XII, No. 1 Juni 2014.

${ }^{11}$ Muhammad Khadru Qaadir, Nafkah Istri Perspektif Hukum Islam, (Majalah Universitas: Fakultas Adab dan Ilmu Sosial Universitas Damam, 2016).
} 
jauh dari harapan. Menurut Fatimah, kedudukan wanita sebagai istri tidak terlindungi atau terjamin haknya. Hal tersebut dapat dilihat dengan tidak ditemukan dalam hukum materil yang secara eksplisit mengatur tentang akibat hukum pasca cerai gugat ${ }^{12}$.

Pemberian hak-hak bagi istri yang dicerai atau gugat cerai meski didasarkan pada kontribusi dalam perkawinan dengan konsep keadilan distributive (justisia distributive) "keadilan adalah memberikan bagian atau hak kepada setiap orang sesuai kontribusi masing-masing." 13 Tujuan utama dari konsep ini yaitu untuk memberikan ruang seluas-luasnya bagi pasangan baik ia sebagai istri atau suami agar bisa mendapatkan hak masing-masing sesuai dengan kontribusinya ketika perceraian terjadi.

\section{Metode}

Tulisan ini merupakan penelitian hukum normatif yang tertulis dikaji dari berbagai aspek seperti aspek teori, filosofi, perbandingan, struktur/ komposisi, konsistensi, penjelasan umum dan penjelasan pada tiap pasal, formalitas dan kekuatan mengikat suatu undang-undang serta bahasa yang digunakan adalah bahasa hukum. Sehingga dapat disimpulkan pada penelitian hukum normatif mempunyai cakupan yang luas. (rujukan) dengan melakukan studi kasus terhadap putusan pengadilan Jakarta Barat tahun 2014-2015 tentang nafkah, mut'ah, dan harta bersama terhadap istri yang dicerai. Penelitian ini menggunakan pendekatan deskriptif yaitu suatu penelitian yang dilakukan dengan tujuan utama mendeskripsikan atau memberikan gambaran mengenai objek penelitian secara objektif.

Data sekunder dari penelitian ini terdiri dari bahan-bahan hukum primer berupa putusan-putusan pengadilan Agama Jakarta Barat tahun 2014-2015 terkait nafkah, mut'ah, dan harta bersama serta Kompilasi Hukum Islam dan undangundang yang terkait. Adapun bahan hukum sekunder dalam penelitian ini berupa buku, jurnal, dan artikel ilmiah yang berhubungan dengan objek penelitian ini.

Penelitian ini merupakan studi kepustakaan dengan mencari, menganalisa, dan memahami data-data sekunder yang ada. Analisis data yang digunakan adalah analisis kualitatif di mana proses penyaringan informasi-informasi yang dihubungkan dengan pemikiran rasional dari sudut pandang teoritis (Moleong, 2005:24).

\section{A. Hak Kepemilikan Harta bagi Istri Cerai \\ 1. Nafkah}

Hakikat nafkah dalam hukum Islam berserta nash-nash syara' telah diuraikan dengan rincin pada bagian sebelumnya. Demikian juga disebutkan dalam undang-undang yang berlaku dalam masyarakat khususnya dalam KHI (kompilasi Hukum Islam) yang menyatakan putusnya perkawinan disebabkan karena kematian, percerian, dan kerena talak ataupun berdasarkan gugatan perceriaan ${ }^{14}$. Adapun yang dimaksudkan dengan gugat cerai ialah cerai yang didasarkan atas adanya gugatan yang diajukan oleh seorang istri agar perkawinan dengan sang

${ }^{12}$ Fatimah, Wanita dalam Hukum Keluarga Islam di Indonesia- studi atas kedudukan Wanita sebagai Ibu, Istri, dan Anak, Pascasarjana UIN Syarif Hidayatullah Jakarta, 2013. (Magelang: Ngudi Ilmu, 2013), h 195.

${ }^{13}$ M. Beni Kurniawan, Pembagian Harta Bersama ditinjau dari Besaran Kontribusi Suami Istri Dalam Perkawinan, Jurnal Yudisial Vol. 11, No. 1. April 2018.

${ }^{14}$ Kompilasi Hukum Islam (KHI), Pasal 113 menyatakan perkawinan dapat putus karena 1) Kematian; 2) Perceraian, dan 3) Atas putusan pengadilan. 
suami menjadi putus ${ }^{15}$. Gugatan terjadi dengan disertai alasan-alasan sebagaimana pasal 19 PP No.9 tahun 1975 penjelasan pasal 39 UU no. 1 tahun 1974 pasal 116 KHI. Dijelaskan juga bahwa laki-laki atau seorang suami adalah pemimpin dalam keluarga dan bertanggung jawab penuh terhadap nafkah istri dan keluarga ${ }^{16}$.

Ikatan pernikahan adalah salah satu sebab diwajibkan nya nafkah diberikan kepada istri. Seorang suami berkewajiban menafkahi anak istrinya. Akan tetapi ketika terjadi pisah antara pasangan suami istri maka sang suami tetap diberikan kewajiban untuk memberikan nafkah ke istri hingga sampai pada masa iddah nya selesai. ${ }^{17}$ Dan tingginya angka perceriaan di Indonesia disebabkan oleh masalah ekonomi. Namun ada juga karena alasan orang ketiga, ketidak harmonisan dan kurang tanggung jawab. Untuk melihat hal perhatikan table berikut.

\begin{tabular}{|c|c|c|c|c|c|c|c|c|c|c|c|c|c|c|c|c|c|}
\hline \multirow[t]{3}{*}{ No } & \multirow{3}{*}{$\begin{array}{l}\text { Pengadilan } \\
\text { Tinggi } \\
\text { Agama }\end{array}$} & \multicolumn{16}{|c|}{ Faktor-Faktor terjadinya Perceraian } \\
\hline & & \multicolumn{3}{|c|}{ Moral } & \multicolumn{4}{|c|}{$\begin{array}{l}\text { Meninggalkan } \\
\text { Kewajiban }\end{array}$} & \multicolumn{4}{|c|}{$\begin{array}{c}\text { Menyakiti } \\
\text { jasmani rohani }\end{array}$} & \multicolumn{4}{|c|}{$\begin{array}{l}\text { Terus menerus } \\
\text { berselisih }\end{array}$} & \\
\hline & & 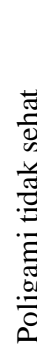 & 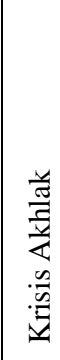 & 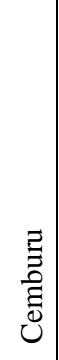 & 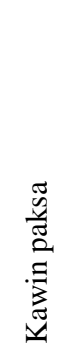 & 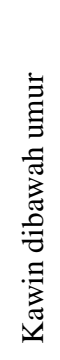 & $\begin{array}{l}\vec{\Xi} \\
\overline{0} \\
\overline{0}\end{array}$ & 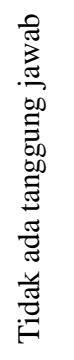 & 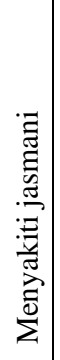 & 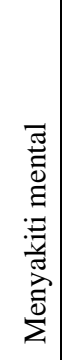 & 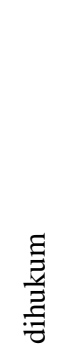 & $\begin{array}{l}\frac{n}{60} \\
\frac{0}{0} \\
0 \\
0 \\
\tilde{J} \\
\tilde{J} \\
0\end{array}$ & $\stackrel{n}{:}$ & 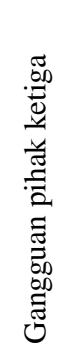 & 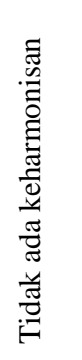 & 寻 & 丞 \\
\hline 1. & $\begin{array}{l}\text { Jakarta } \\
\text { Barat }\end{array}$ & - & - & - & - & 11 & 583 & 852 & - & - & - & - & - & 60 & 430 & - & 1915 \\
\hline
\end{tabular}

Dari 1915 kasus perceraian diatas, 852 kasus dipicu oleh karena tidak adanya tanggung jawab dalam rumah tangga yang menempati faktor pertama dalam kasus perceraian di tahun 2014, kemudian disusul oleh faktor ekonomi dengan jumlah kasus 583, tidak adanya keharmonisan mencapai 430 kasus, gangguan pihak ketiga, masuk dalam peringkat keempat yaitu 60 kasus, dan terakhir disebabkan faktor kawin di bawah umur berjumlah 11 kasus $^{18}$.

Kepala pusat penelitian dan pengetahuan (Puslitbang) kehidupan keagamaan Kementrian Agama, Muharram Marzuki menyebutkan, angka perceraian di Indonesai lima tahun terakhir terus meningkat. Pada tahun 2011-2015, dari sekitar 2 juta pasangan menikah, 15 persen diantaranya bercerai. ${ }^{19}$ Hal serupa juga dikemukan oleh wakil Menteri Agama bahwa ada sekitar 2.000.000 (dua juta) pasangan menikah setiap tahunnya, sekitar 200.000 (dua ratus ribu) pasangan bercerai setiap tahunnya. Angka perceraian $10 \%$ dari angka pernikahan ini. Itu

\footnotetext{
${ }^{15}$ Ahmad Azhar Basyir, Hukum Perkawinan Islam, (Yogyakarta: UII Press, 2007), h 88.

${ }^{16}$ Wahyu Ernaningsih dan Putu Samawati, Hukum Perkawinan Indonesia, (Palembang: PT Rambang Palembang, 2008), h 129.

${ }^{17}$ Fatimah, Wanita dalam Hukum Keluarga Islam di Indonesia- studi atas kedudukan Wanita sebagai Ibu, Istri, dan Anak, Pascasarjana UIN Syarif Hidayatullah Jakarta, 2013, h 195.

${ }^{18}$ Sumber: Laporan tahunan Pengadilan Agama Jakarta Barat tahun 2014-2015.

${ }^{19}$ Kementrian Agama, Angka Perceraian di Indonesia Tinggi, tanggal Juni 2016. www.eksposnews.com.
} 
berarti terdapat 1 perceraian setiap 10 pernikahan. Uniknya, hampir $70 \%$ justru istri yang menceraikan suami (gugat cerai) dan hanya 30 persen suami yang menceraikan. ${ }^{20}$
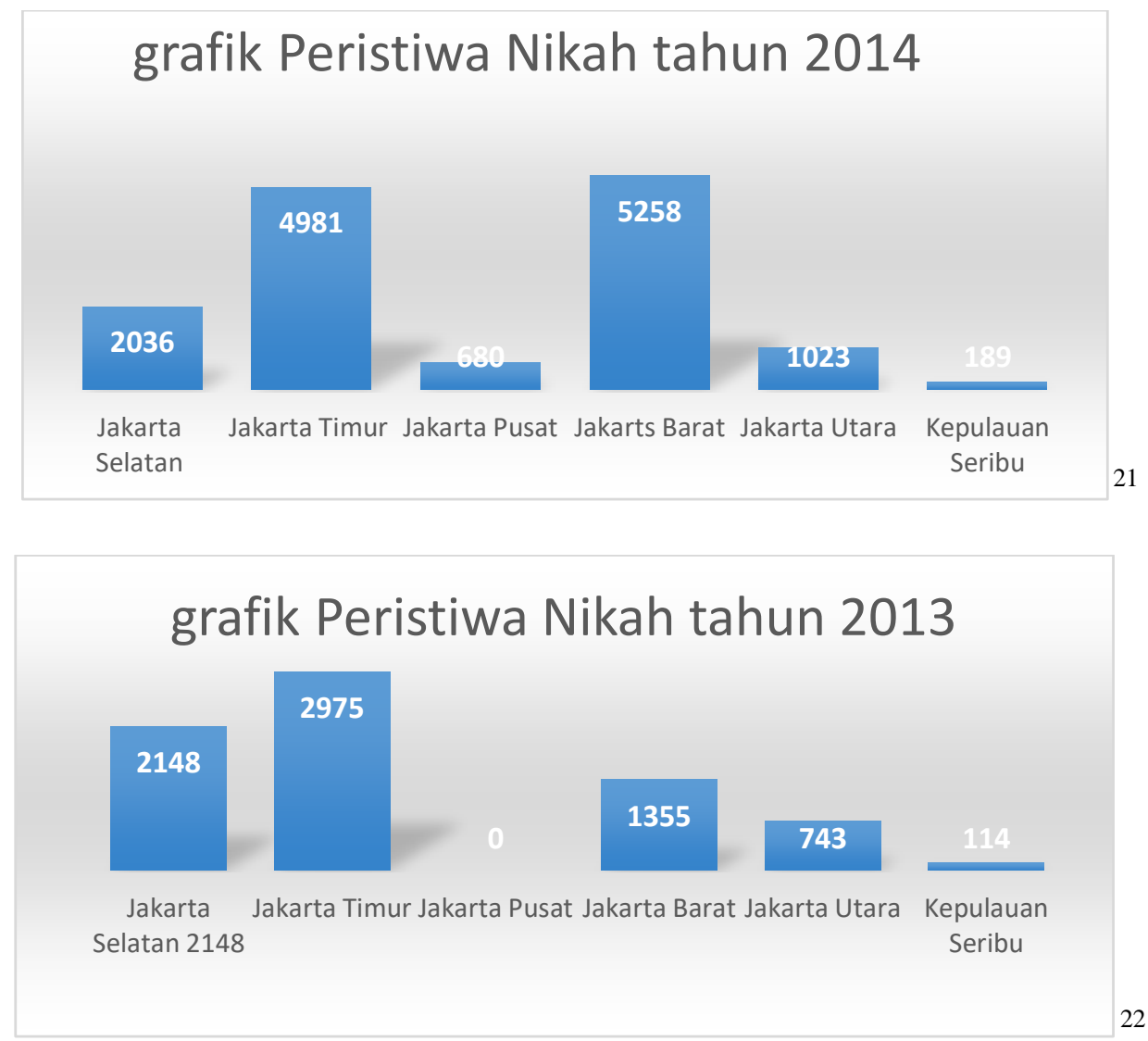

Melihat dari tabel diatas dapat diterangkan bahwa jumlah keseluruhan pernikahan selama 1 tahun sejak 2014 sudah mencapai 14.167 pasangan yang menikah. Sedangkan pada tahun 2013 pasangan menikah mencapai 7335 pasangan $^{23}$.

Diberikannya hak cerai kepada istri dimaksudkan agar para istri mempunyai jalur hukum yang bisa ditempuh untuk melepaskan diri dari kungkungan atau cengkeraman serta kesewenang-wenangan para suami. Talak tetap menjadi hak preogratif suami. Hal itu dimaksudkan untuk melindungi hak-hak kaum wanita yang selama ini tidak diberikan kepada mereka hanya suamilah yang berhak memutuskan hubungan perkawinan. Sementara kaum wanita harus menerima keputusan yang tidak menguntungkanya. Berdasarkan data hasil penelusuran di Pengadilan Agama DKI Jakarta sepanjang tahun 2014-2015, perbandingan jumlah kasus cerai talak dan cerai gugat sangat signifikan. Hal ini dapat dilihat pada tabel di bawah ini.

\footnotetext{
${ }^{20}$ Kementrian Agama, Angka Perceraian di Indonesia Tinggi, tanggal Juni 2016. www.eksposnews.com.

${ }^{21}$ Sumber: Laporan tahunan Pengadilan Agama Jakarta Barat tahun 2014-2015.

${ }^{22}$ Sumber: Laporan tahunan Pengadilan Agama Jakarta Barat tahun 2014-2015.

${ }^{23}$ Kementrian Agama, Info Pernikahan di Indonesai, tanggal 16 Juni 2016 melalui www.kemenag.go.id.
} 
Tabel

Perkara Permohona Cerai Talak yang diterima dan diputus Pengadilan Agama Jakarta Barat 2014-2015.

\begin{tabular}{|l|l|l|l|}
\hline No & Pengadilan Agama & Perkara Diterima & Perkara Diputus \\
\hline 1. & Jakarta Barat & 1216 & $1149^{24}$ \\
\hline
\end{tabular}

Berdasarkan tabel di atas menunjukkan bahwa dalam perkara permohonan cerai talak yang diterima di wilayah Pengadilan Agama Jakarta Barat dalam kurun waktu 2014 sampai 2015 mencapai angka 1.216 perkara, dan yang berhasil diputus bejumlah 1.149 kasus, dengan 67 kasus yang belum diputus.

Tabel

Perkara Permohona Cerai Gugat ynaag diterima dan diputus Pengadilan Agama Jakarta Barat 2014-2015.

\begin{tabular}{|l|l|l|l|}
\hline No & Pengadilan Agama & Perkara Diterima & Perkara Diputus \\
\hline 1. & Jakarta Barat & 3456 & $3227^{25}$ \\
\hline
\end{tabular}

Tabel di atas menunjukkan bahwa, dalam kurun waktu dua tahun (20142015) perkara cerai gugat yang diterima di wilayah Pengadilan Agama Jakarta Barat mencapai angka 3.456 perkara, dan yang berhasil diputus bejumlah 3.227 perkara, dengan 229 perkara yang belum diputus.

\section{Hadiah/Mut'ah}

Perkawinan adalah ikatan yang suci dan mempunyai tujuan dan cita cita yang mulia. namun adakala suatu perkawinan putus karena alasan tertentu, terjadilah perceraian antara suami istri di pengadilan agama ${ }^{26}$. Putusnya ikatan perkawinan di dalam fiqih Islam dikenal dengan Talak dan khulu' sedangkan dalam KHI disebut dengan cerai talak dan cerai gugat ${ }^{27}$.

Mut'ah merupakan pemberian suami kepada istri yang diakibatkan karena talak dari suami. Pemberian tersebut bermaksud untuk menyenangkan suasana hati dari istri. Selain itu mut'ah juga berarti penghargaan dari suami kepada istri, atas kesetiaan yang telah diberikan istri kepada suami pada saat masa perkawinan. Mut'ah merupakan suatu kewajiban yang harus dipenuhi oleh suami pada saat terjadi proses perceraian ketika suami mengajukan talak kepada istri ${ }^{28}$.

Kewajiban suami dalam memberikan mut'ah sesuai dengan ketentuan pasal 149 KHI yang menyatakan bahwa suami wajib memberikan mut'ah yang layak kepada istrinya kecuali pada saat Qobla dukhul ${ }^{29}$. Pada saat istri belum digauli, seorang suami tidak memiliki kewajiban untuk memberikan mut'ah kepada istri. Akan tetapi pada saat Qobla dukhul seorang suami boleh memberikan mut'ah

\footnotetext{
${ }^{24}$ Sumber: Laporan Tahunan Pengadilan Agama DKI Jakarta Tahun 2014- 2015.

${ }^{25}$ Sumber: Laporan Tahunan Pengadilan Agama DKI Jakarta Tahun 2014- 2015.

${ }^{26}$ Kamal Muchtar, Asas-asas Hukum Islam Tentang Perkawinan, (Jakarta: Bulan Bintang, 2004), h. 135.

${ }^{27}$ Hilman Hadikusumah, Hukum Perkawinan Indonesia Menurut Undang-Undang Hukum Adat, Hukum Agama, (Bandung: Mandar Maju, 2000), h. 167.

${ }^{28}$ Sumber: Wawancara bersama Bapak Ubaidillah selaku hakim Pengadilan Agama Jakarta Barat, pada tanggal 16 Juni 2016.

${ }^{29}$ Kompilasi Hukum Islam (KHI), Pasal 149 bilamana perkawinan putus karena talak, maka bekas suami wajib: memberikan mut ah yang layak kepada bekas isterinya, baik berupa uang atau benda, kecuali bekas isteri tersebut qobla al dukhul.
} 
kepada istri. Dalam pemberian mut'ah pada saat qobla dukhul, bagi suami, mut'ah bersifat sunnah. Walaupun tidak diwajibkan untuk memberikan mut'ah suami boleh memberikan mut'ah terhadap istri yang telah di $\operatorname{talak}^{30}$. Pengadilan Agama selaku pihak yang diberikan wewenang oleh negara untuk mengatur hal-hal yang bersangkutan dengan masalah keperdataan mempunyai peran yang sangat signifikan bagi terselenggaranya kemaslahatan antara kedua belah pihak berkaitan dengan $m u t$ 'ah suami kepada istri. Berikut urian terkait proses dalam pemberian mut'ah: ${ }^{31}$ Pertama: Pembayaran mut'ah secara tunai diserahkan langsung kepada istri setelah suami selesai membacakan ikrar talak di hadapan majelis hakim dengan dihadiri oleh istri. Biasanya dalam pemberian mut'ah secara langsung ini, besarnya mut'ah terjangkau oleh suami dan telah dipersiapkan suami setelah dibacakannya amar putusan oleh majelis hakim, dan pada saat itu pula suami memberikan secara langsung pada saat sidang ikrar talak, dan besarnya mut'ah telah dipersiapkan oleh suami. Pembayaran mut'ah secara tunai, dapat juga dilakukan dengan cara menitipkan mut'ah tersebut kepada Pengadilan Agama. Pada proses ini, suami menitipkan sebagian atau seluruhnya mut'ah kepada Pengadilan Agama. Setelah suami mengucapkan ikrar talak pada sidang ikrar talak, istri dapat mengambil mut'ah tersebut di Pengadilan. Kedua:Pemberian mut'ah dapat dilaksanakan dengan cara diangsur, pembayarannya berdasarkan kesepakatan antara suami dan istri. Ketika suami sanggup memberikan mut'ah tersebut tetapi dengan catatan diangsur selama 2 bulan atau 3 bulan atau beberapa bulan berdasarkan kesepakatan, kemudian istri menerima, karena yang mengerti tentang keadaan dari suaminya tersebut adalah istrinya itu sendiri.

Apabila suami sudah menyanggupi untuk membayar secara di angsur, tetapi dalam pelaksanaannya, suami tersebut mengingkari, maka istri bisa mengajukan permohonan eksekusi ke Pengadilan. Karena pemberian atau pembebanan mut'ah tersebut sifatnya wajib, dan dituangkan dalam amar putusan. Jika suami tidak melaksakan kewajiban tersebut, tetapi istri tidak mengajukan permohonan eksekusi, berarti istri tersebut menerima tentang perlakuan dari suami dan Pengadilan Agama menganggap jika pemberian $m u t$ ' $a h$ telah dilaksanakan dengan baik $^{32}$.

Berdasarkan hal tersebut dapat diambil kesimpulan bahwa kontrol dari pihak Pengadilan Agama memberikan pengaruh signifikan, semakin tinggi tingkat kontrol yang diberikan maka semakin tinggi pula tingkat keberhasilan mut'ah suami kepada mantan istri. Dan begitu sebaliknya semakin rendah tingkat kontrol maka semakin jauh tingkat keberhasilan yang diharapkan. Selain kontrol Pengadilan Agama terhadap pelaksanaan mut'ah sanksi hukum yang tegas juga memberikan sumbangan yang besar bagi terselangaranya mut'ah suami terhadap mantan istri. Sejauh ini tidak ada sanksi hukum yang diberikan oleh pihak terkait dengan tidak dilaksananya mut'ah tersebut. Sehingga hal ini menyebabkan rendahnya kesadaran hukum yang pada akhirnya mut'ah suami terhadap istri atau mantan istri tidak terlaksana dengan baik karena sang suami merasa tidak ada akibat dari dilaksakannya mut'ah tersebut. ${ }^{33}$

\footnotetext{
${ }^{30}$ Muhammad Anshary, Harta Bersama Perkawinan dan Permasalahannya, (Bandung: Bandar Maju, 2016), h. 50.

${ }^{31}$ Sumber: wawancara bersama Bapak Ubaidillah selaku hakim Pengadilan Agama Jakarta Barat, pada tanggal 16 Juni 2016.

${ }^{32}$ Mohammad Idris Ramulyo, Hukum Perkawinan Islam, Suatu analisis Undang-undang Nomor 1 Tahun 1974 dan Kompilasi Hukum Islam, (Jakarta : PT. Bumi Aksara, 2010), h 100.

${ }^{33}$ Soemiyati, Hukum Perkawinan Islam dan Undang-Undang Perkawinan, (Yogyakarta: Liberty, 2007), h. 87.
} 


\section{Harta Bersama}

\section{Pandangan Sarjana Hukum Terhadap Harta Bersama}

Harta bersama merupakan problem yang memiliki pengaruh terhadap kehidupan suami istri, apalagi jika keduanya bercerai. sehingga timbul berbagai macam hukum yang kadang-kadang dalam penyelesaiannya menyimpang dari peraturan perundang-undangan yang berlaku. ${ }^{34}$ Kajian tentang harta bersama tidak dijumpai dalam kitab-kitab fikih klasik. ${ }^{35}$ Masalah harta bersama merupakan persoalan hukum yang belum disentuh oleh ulama-ulama fikih klasik karena alasan bahwa tema ini muncul dan banyak dibicarakan di masa modern. ${ }^{36}$

Menurut hukum Islam ada dua versi jawaban yang dapat dikemukakan terkait tentang harta bersama karena para ahli hukum Islam berbeda pendapat tentang harta bersama ini. ${ }^{37}$ Dalam bukunya Abdul Manan, Anwar Harjono, dan Abdoerraoef mengatakan bahwa dalam hukum Islam tidak mengatur tentang harta bersama, karena itu diserahkan sepenuhnya kepada pribadi masing-masing untuk mengaturnya. Sebagian sarjana hukum yang lainnya termasuk T. Jafizham mengatakan bahwa suatu hal yang tidak mungkin jika agama Islam tidak mengatur tentang harta bersama, sedangkan perkara kecil-kecil saja diatur secara rinci oleh hukum Islam dan ditentukan dasar hukumnya. ${ }^{38}$

Harta bersama diistilahkan dengan shirkah. yang telah ditulis dalam kitabkitab fikih klasik, khususnya bab mu'amalah. ${ }^{39}$ Harta bersama dikategorikan sebagai shirkah mufawwadah atau juga shirkah 'abdaan. ${ }^{40}$ Sedangkan harta warisan dan pemberian milik keduanya merupakan pengecualian. ${ }^{41}$ Jika harta bersama diqiyaskan dengan shirkah dengan argumen mengandung pengertian sebagai suatu bentuk perkongsian atau kerja sama antara suami dan istri. Sedangkan shirkah harta bersama sifatnya hanya kerja sama dalam membangun sebuah rumah tangga yang sakinah, mawaddah, dan rahmah, meskipun juga meliputi hal-hal yang berkaitan dengan harta dalam perkawinan. ${ }^{42}$

Sajuti Thalib dan M. Idris Ramulyo berpendapat bahwa, bertitik tolak pada al-Qur'an, ${ }^{43}$ hukum Islam mengakui harta yang diperoleh suami istri karena

\footnotetext{
${ }^{34}$ Abdul Manan, Aneka Masalah Hukum Perdata Islam di Indonesia, (Jakarta: Kencana, 2006), h. 103.

${ }^{35}$ Wawancara dengan Abd. Rasyid As'ad, hakim Pengadilan Agama Kraksaan pada tanggal
} 09 Juni 2016.

${ }^{36}$ Ra'd Kamil Hayati, Memecahkan Perselisihan Keluarga Menurut Qur'an dan Sunnah, (Yogyakarta: Mitra Pustaka, 2004), h. 64.

${ }^{37}$ Mohammad Idris Ramulyo, Hukum Perkawinan Islam, h. 230.

${ }^{38}$ Abdul Manan, Aneka Masalah Hukum Perdata Islam di Indonesia, h. 109. Lihat pula T. Jafizham, Persentuhan Hukum di Indonesia dengan hukum perkawinan Islam, h. 119.

${ }^{39}$ Harta bersama suami istri mestinya masuk dalam rub'umu'amalah, tetapi ternyata tidak dibicarakan secara khusus. Hal ini mungkin disebabkan karena pada umumnya pengarang kitabkitab fikih adalah orang Arab yang tidak mengenal adanya pencarian harta bersama suami istri. Tetapi dibicarakan tentang kongsi yang dalam bahasa Arab disebut shirkah. Oleh karena masalah pencarian bersama suami istri adalah termasuk perkongsian atau shirkah, lihat Cik Hasan Bisri, Kompilasi hukum Islam dalam Sistem Hukum Nasional, (Ciputat: Logos Wacana Ilmu, 1999), h. 62. Abdul Manan, Aneka Masalah Hukum Perdata Islam di Indonesia, h. 111.

${ }^{40}$ Kenyataan yang terjadi di sebagian besar masyarakat Indonesia, pasangan suami istri sama-sama bekerja dalam hal mencari nafkah untuk mencukupi kebutuhan hidup rumah tangganya, Di samping untuk tabungan hari tua dan sebagai peninggalan bagi anak-anaknya kelak. Lihat Khoiruddin Nasution, Hukum Perkawinan, (Yogyakarta: Academia dan Tazzafa,2005), h. 92.

${ }^{41}$ Mohd. Idris Ramulyo, Hukum Perkawinan Islam, h. 232.

${ }^{42}$ R.Wirjono Prodjodikoro, Hukum Perkawinan di Indonesia, (Jakarta: Sumur Badung, 1960), h. 68.

${ }^{43}$ Surah al-Nisa Ayat 19, 21,dan 34. Surah al-Baqarah Ayat 228. 
usahanya adalah harta bersama, baik mereka bekerja bersama-sama atau hanya suami saja yang bekerja, Sekali mereka terikat dalam perjanjian perkawinan sebagai suami istri, maka semuanya menjadi bersatu baik mengenai harta maupun mengenai anak-anak. ${ }^{44}$ Tidak perlu diiringi dengan shirkah. ${ }^{45}$ Demikian halnya bilamana suami saja yang bekerja, berusaha dan mendapatkan harta, tidak dapat dikatakan bahwa harta itu milik suami saja, melainkan telah menjadi harta bersama antara suami istri. Apabila terjadi perceraian, maka harta bersama yang diperoleh selama dalam perkawinan itu harus dibagi dua menurut pembagian yang sama. ${ }^{46}$

\section{B. Analisis Putusan Pengadilan Agama Jakarta Barat Terkait Harta Bersama}

Perceraian mempunyai akibat hukum tidak hanya terhadap diri pribadi, tetapi juga akibat hukum terhadap harta kekayaan suami istri yang diperoleh selama perkawinan. Lalu bagaimana pertimbangan hakim dalam menentukan pembagian harta bersama akibat perceraian. ${ }^{47}$

Ada beberapa contoh kasus putusan Mahkamah Agung No. 803 K/Sip/1970 tanggal 5 Mei 1971. Dalam putusan ini dijelaskan bahwa harta yang dibeli suami atau istri di tempat yang jauh dari tempat tinggal adalah termasuk harta bersama suami istri jika pembelinya dilakukan selama perkawinan. ${ }^{48}$ Lain halnya jika uang pembeli barang berasal dari harta pribadi suami istri, maka barang tersebut tidak menjadi objek harta bersama melainkan menjadi milik pribadi. Hal ini dapat dilihat pada putusan Mahkamah Agung tanggal 16 desember 1975 No.151 K/Sip/1974. ${ }^{49}$

Dari putusan tersebut, terdapat 2 hal yang menjadi persoalan. Pertama: apakah harta benda yang diperoleh sebagai hasil pengembangan dari harta bersama yang belum dibagi setelah terjadinya perceraian. Kedua: andai kata harta tersebut termasuk harta bersama, lalu bagaimana pembagiannnya. ${ }^{50}$

\footnotetext{
${ }^{44}$ Mohammad Idris Ramulyo, Hukum Perkawinan Islam, h. 205.

${ }^{45}$ Bilamana istri hamil, kemudian melahirkan seorang anak, sedangkan suami tidak ikut mengandung anak yang dikandung istrinya itu, dan tidak pula turut serta melahirkan anak, tetapi anak tersebut tidak dapat dikatakan anak istri saja, tentu tidak, sebab anak itu adalah anak hasil dari perkawinan, bahkan lazimnya lebih ditonjolkan kepada nama suami atau ayah di belakang nama anak. Lihat Fatimah, Wanita Dalam Hukum Keluarga di Indonesia-Study atas Kedudukan Wanita sebagai Ibu, Istri, Anak, Pascasarjana UIN Syarif Hidayatullah Jakarta, 2013, h. 195.

${ }^{46}$ Setiap barang yang diperoleh selama perkawinan maka secara otomatis harta tersebut menjadi objek harta bersama suami istri, tanpa mempersoalkan siapa yang memiliki kontribusi yang lebih banyak dalam perolehan harta bersama tersebut, seperti siapa yang membeli, terdaftar atas nama siapa, dan harta tesebut berada dibawah penguasaan siapa. Hal ini berdasarkan pada ketentuan UU perkawinan pasal 35 ayat 1, yang kemudian di pertegas dalam KHI pasal 1 huruf (F). lihat Abdul Manan, Aneka Masalah Hukum Perdata Islam di Indonesia, h. 112.

${ }^{47}$ Muhammad Anshary, Harta Bersama Perkawinan dan Permasalahannya, h. 47.

${ }^{48}$ M.Yahya Harahap, (menukil dari yurispudensi Jawa Baarat 1969-1972, h. 31), 1997, Keduduakn Kewenangan dan Acara Peradilan Agama (undang undang No.7 Tahun 1989), Penerbit Pustaka Kartini, Jakarta, h. 303.

${ }^{49}$ Bagaimana halnya dengan harta yang diperoleh dari hasil pengembangan harta bersama yang dikuasai oleh salah satu pihak dari suami atau istri setelah terjadi perceraian? diumpamakan setelah terjadi perceraian, harta bersama belum dibagi dan keseluruhan harta bersama tersebut dikuasai mantan suami, kemudian harta bersama tersebut terdapat satu unit pabrik yang bernilai sangat produktif, sehinggga dari hasil pabrik sejak terjadinya perceraian telah memperoleh keuntungan sehingga mantan suami dapat membeli beberapa objek barang harta benda lainnya, misalnya beberapa unit ruko. Lihat M. Yahya Harahap, (menukil dari yurispudensi Jawa Barat 19691972, h 31), 1997, Keduduakn Kewenangan dan Acara Peradilan Agama (undang undang No.7 Tahun 1989), Penerbit Pustaka Kartini, Jakarta, h. 303.

${ }^{50}$ Bagaimana perolehan masing-masing mantan suami istri tersebut? Sebab perlu ditegaskan bahwa yang mengelola harta bersama setelah terjadinya perceraian sehingga menghasilkan beberapa unit ruko tersebut adalah mantan suami, sementara mantan istri tidak diberi kesempatan oleh suami untuk mengelola harta bersama tersebut.
} 
Apabila terjadi kasus yang diajukan kepengadilan sebagaimana tersebut diatas, oleh karena tidak ditemukan dalam UU Perkawinan dan $\mathrm{KHI}^{51}$ dan juga dalam KUHPerdata, maka acuan penyelesaiannya merujuk kepada yurispudensi Mahkamah Agung, bahwa harta benda yang dibeli dan dibangun sesudah perceraian yang dibiayai dari harta bersama, untuk menentukan sesuatu barang termasuk objek harta bersama dapat ditentukan oleh asal usul uang biaya pembelian atau pembangunan barang yang bersangkutan, meskipun barang yang dibeli atau dibangun sesudah terjadinya perceraian. Praktek ini sesuai dengan Putusan Mahkamah Agung tanggal 5 Mei 1970 No.803K/Sip/1970 yakni, apa saja yang dibeli setelah terjadinya perceraian, jika uangnya berasal dari harta bersama maka dalam barang tersebut melekat harta bersama meskipun telah berubah wujudnya. ${ }^{52}$ Dari putusan Mahkamah Agung tersebut harus ditafsirkan bahwa siapa saja yang menguasai dan mengelola harta tersebut, maka secara hukum harus dipandang sebagai harta bersama mantan suami dan istri. ${ }^{53}$

Berdasarkan temuan penulis di PA Jakarta Barat dalam kasus sengketa harta bersama dari tahun 2014-2015 menunjukkan bahwa, PA Jakarta Barat dari tahun 2014-2015 memiliki 15 kasus. Dengan rincian, perkara yang masuk tahun 2014 sebanyak 5 perkara. Perkara yang diptus sebanyak 7 kasus. 2 kasus merupakan kasus lanjutan dari tahun 2013. Pada tahun 2015 tealh diterima 10 kasus, dan perkara yang telah berhasil diputus berjumlah 6 kasus. Dari tahun 2014-2015 di PA Jakarta Barat terdapat 13 kasus. Sisanya masih dalam proses persidangan. Untuk lebih jelasnya dapat dilihat pada tabel dibahwah ini:

Tabel

Perkara Permohonan Harta Bersama yang diterima dan dipitus Pengadilan Agama Jakarta Barat Tahun 2014-2015

\begin{tabular}{|c|c|c|c|}
\hline No & Pengadian Agama & Perkara diterima & Perkara diputus \\
\hline 1. & Jakarta Barat & 15 & $13^{54}$ \\
\hline
\end{tabular}

Dalam kasus yang dikutip di atas, pihak penggugat adalah istri yang mengajukan gugatan perceraian ke pengadilan agama sekaligus menguatkan pembagian harta bersama.

Hakim dalam memutus suatu perkara, disamping harus memperhatikan faktor yuridis (legal justice), juga harus memperhatikan faktor sosiologis (social justice), Dalam kasus ini tidak menutup kemungkinan suami memperoleh $2 / 3$ bagian dari harta benda tersebut, sementara mantan istri mendapat $1 / 3$ bagian saja.

\footnotetext{
${ }^{51}$ Jika kembali melihat pada UU perkawinan dan KHI yang mangatur segala harta benda yang diperoleh selama perkawinan merupakan harta bersama, sebagaimana yang diatur dalam UU perkawinan pasal 35 ayat 1 dan juga dalam KHI pasal 1 huruf f. Adapun harta benda yang diperoleh sebagai hasil pengembangan dari harta bersama yang belum dibagi setelah terjadinya perceraian, tidak diatur dalam hukum. Lihat Muhammad Anshary, Harta Bersama Perkawinan dan Permasalahannya, h. 136.

${ }^{52}$ Hilman Hadikusuma, Hukum Perkawinan Indonesia Menurut: Perundangan Hukum Adat Hukum Agama, h. 137.

${ }^{53}$ Dalam hukum perdata, pembuktian merupakan kunci untuk dikabulkannya atau di tolaknya suatu gugatan. Oleh sebab itu jika mantan istri ataupun mantan suami dapat membuktikan dalil-dalil gugatannya berdasarkan alat-alat bukti yang telah ditentukan oleh undang-undang, maka majlis hakim akan mengabulkann gugatan tersebut. Tetapi jika sebaliknya, maka majlis hakim akan menolak gugatan tersebut. Lihat Abdul Manan, Aneka Masalah Hukum Perdata Islam di Indonesia, h. 105 .

${ }^{54}$ Sumber: Laporan tahunan Pengadilan Agama Jakarta Barat tahun 2014-2015.
} 


\section{Analis Hak Kepemilikan Harta Bersama bagi Istri Cerai}

Gugatan harta bersama dapat diajukan bersama-sama secara kumulatif dengan gugatan perceraian. Pasal ini memberi kesempatan kepada penggugat untuk mengajukan gugatan tentanng harta bersama pada dua kemungkinan. Pertama: gugatan harta bersama dapat diajukan bersama-sama gugatan perceraian. Kedua: dapat diajukan sesudah putusan gugatan perceraian mempunyai kekuatan hukum tetap. Ini artinya gugatan soal harta bersama diajukan tersendiri setelah perceraian terjadi dengan nomor perkara tersendiri yang berbeda dengan nomor perkara perceraian. ${ }^{55}$

Dalam perundang-undangan diatur mengenai pembagaian harta bersama suami istri apabila terjadi perceraian sebagaimana yang telah diatur dalam $U U$ perkawinan No.1 tahun 1974 pasal 37. ${ }^{56}$ Aturan-aturan dimaksud bentuk intruksi Presiden berupa Kompilasi Hukum Islam, sebagaimana disebutkan pada bagian sebelumnya. ${ }^{57}$

Dari putusan ketiga pengadilan tersebut ada putusan yang dinilai menyimpang dari ketentuan perundang-undangan, yakni suami mendapat $1 / 4$ bagian dan bagian sang istri $3 / 4$ bagian. Putusan tersebut dijatuhkan berdasarkan keterangan penggugat dan tergugat serta berdasarkan hasil pembuktian yaitu keteranganketerangan saksi. Pertimbangan Mahkamah Agung tersebut jelas bahwa yang bertagggung jawab bekerja dan mencari nafkah dalam suatu keluarga ialah suami. ${ }^{58}$

Tugas yang diberikan undang-undang terhadap seorang istri secara hukum mempunyai nilai yang sama dengan tugas yang diberikan kepada suami. ${ }^{59}$ Dengan demikian semua perolehan suami selama perkawinan menjadi harta bersama, dan apabila terjadi perceraian, maka berlaku ketentuan pasal 37 UU perkawinan dan juga pasal 97 Kompilasi hukum Islam menyebutkan bahwa masing-masing berhak mendapat $1 / 2$ dari harta bersama. ${ }^{60}$ Tetapi jika sang suami tidak bersedia meyerahkan bagian istri, maka sang istri berhak mengajukan gugatan tentang pembagian harta bersama ke pengadilan. ${ }^{61}$ Jika terjadi cerai mati dimana suami lebih dulu meninggal, maka harta perkawinan tersebut lebih dahulu dibagi 2, separuh unutk istri dan separuh untuk bagian almarhum suami, dan bagian suami dari harta bersama itu menjadi bagian warisan suami yang wajib dibagi kepada ahli warisnya sebagaimana diatur dalam KHI pasal 96.

\footnotetext{
${ }^{55}$ Berdasarkan pasal 86 ayat (1) undang undang Nomor 7 tahun 1989 tentang peradilan agama yang telah dirubah dengan undang undang Nomor 3 tahun 2006 dan perubahan kedua undang undang Nomor 50 tahun 2009 121. Gugatan perceraian yang digabung dengan gugatan pembagian harta bersama adalah hal yang dibenarkan oleh undang undang yang berbunyi: "Gugatan soal penguasaan anak, naafkah anak, nafkah istri dan harta bersama suami istri dapat diajukan bersamasama dengan gugatan perceraian ataupun sesudah keputusan perceraian memperoleh kekuatan hukum tetap.

${ }^{56}$ UU perkawinan No.1 tahun 1974 pasal 37 menyatakan bahwa: apabila perkawinan putus karena peceraian, harta bersma diatur menurt hukumnya masing asing. Yang dimaksud hukumnya masing masing adlah: Hukukm Agama, Hukum Adat, dan Hukum Lainnya.

57 Menurut ketentuan Kompiasi Hukum Islam, baik kasus cerai mati ataupun cerai hidup, masing-masing pasangan mendapat bagian $1 / 2$ bagian dari harta bersama.

${ }^{58}$ Sebagaimana yang diatur dalam UU Perkawinan pasal 34 ayat (1): "Suami wajib melindungi istrinya dan memberikan segala sesuatu keperluan hidup berumah tangga sesuai kemempuannya".

${ }^{59}$ Abdurrahman, Kompilasi Hukum Islam (KHI) , h. 133.

${ }^{60}$ Muhammad Anshary, Harta Bersama Perkawinan dan Permasalahannya, h. 127

${ }^{61}$ Pasal 96 ayat (1), yang berbunyi: "Apabila terjadi cerai mati, maka separuh harta bersama menjadi hak pasangan yang hidup lebih lama”.
} 


\section{Kesimpulan}

Melalui uraian ini dapat disimpulkan bahwa hak-hak kepemilikan harta benda setelah bercerai sesuai dengan kebutuhannya. Dan syariat Islam tidak membolehkan bagi perempuan keluar rumah untuk bekerja. Pendapat ini diutarakan oleh syekh Muhammad Muthawali Syarawi dan Wahidudin Khaan. Hal yang berbeda diungkapkan oleh imam Abu Hanifah, Hazam al Zhahiriyah dan Mustafa as Sibai, hak-hak harta yang melekat pada istri yang pisah diberikan sesuai dengan kebutuhannya. Syariat Islam membolehkan bagi perempuan keluar rumah untuk bekerja.

Dalam undang-undang keluarga Indonesia dikatakan bahwa hak yang melekat pada istri yang bercerai adalah nafkah, pemberian, dan harta bersama. Dan undang-undang menjamin kesamaan hak kepemilikan harta bagi perempuan. Namun pemberian hak kepemilikan harta tetap merujuk kepada kemampuan yang dimiliki oleh sang suami. Meski demikian tidak ada batasan ataupun ketentuan mengenai ukuran yang sah untuk diberikan kepada pasangan khususnya istri yang pisah.

Putusan pengadilan Agama Jakarta Barat dari tahun 2014-2015 mengenai hak-hak kepemilikan harta berupa nafkah, pemberian, dan harta bersama telah sesuai dengan ketentuan yang ada di KHI (Kompilasi Hukum Islam). Pengadilan Agama memiliki peranah penting dalam memberikan keadilan dan status kepemilikan harta bagi istri karena alasan perceraian.

\section{Daftar Pustaka}

Abdul Manan. Aneka Masalah Hukum Perdata Islam di Indonesia. Jakarta: Kencana, 2006.

Ahmad Azhar Basyir. Hukum Perkawinan Islam. Yogyakarta: UII Press, 2007.

Asniar, Khumas. Model Penjelasan Intensi Cerai Perempuan Muslim di Sulawesi Selatan. Jurnal Psikologi: Vol. 42, No. 3, Desember 2015.

Dewi Judiasih, Sonny. Harta Benda Perkawinan. Bandung: Refika Aditama. 2015

Fachrina dan Rinaldi Eka Putra. Upaya Pencegahan Perceraian Berbasis Keluarga Luas dan Institusi Lokal dalam Masyarakat Minangkabau di Sumatra Barat, Antropologi Indonesia Vol. 34, No. 2. 2013, h. 102.

Fatimah. Wanita dalam Hukum Keluarga Islam di Indonesia- studi atas kedudukan Wanita sebagai Ibu, Istri, dan Anak, Pascasarjana UIN Syarif Hidayatullah Jakarta. 2013. Magelang: Ngudi Ilmu, 2013.

Hadikusumah. Hukum Perkawinan Indonesia Menurut Undang-Undang Hukum Adat, Hukum Agama. Bandung: Mandar Maju, 2000.

Khofifah Indar Parawansa, Mengukir Paradigma Menembus Tradisi: Pemikiran Tentang Keserasian Jender. Jakarta: LP3ES, 2006.

M. Anshary, Harta Bersama Perkawinan dan Permasalahannya. Bandung: Bandar Maju, 2016.

M. Beni Kurniawan. Pembagian Harta Bersama ditinjau dari Besaran Kontribusi Suami Istri Dalam Perkawinan. Jurnal Yudisial Vol. 11, No. 1. April 2018.

M. Idris Ramulyo. Hukum Perkawinan Islam. Suatu analisis Undang-undang Nomor 1 Tahun 1974 dan Kompilasi Hukum Islam. Jakarta : PT. Bumi Aksara, 2010.

M. Khadru Qaadir. Nafkah Istri Perspektif Hukum Islam. Majalah Universitas: Fakultas Adab dan Ilmu Sosial Universitas Damam, 2016.

Muchtar, Kamal. Asas-asas Hukum Islam Tentang Perkawinan. Jakarta: Bulan Bintang, 2004. 
Nunung, Rodliyah. "Perceraian Pasangan Muslim Berpendidikan Tinggi. Studi Kasus di Kota Bandar Lampung” UIN Sunan Kalijaga. 2011.

Nur. Azizah Hatugalung. Edi Gunawan. Taklik Talak dan Akibat Hukumnya Dalam Kompilasi Hukum Islam Perspektif Teori Feminis. Al-Mizan: Jurnal Pemikiran Hukum Islam, Vol. 15, No.1, 2019.

Rais, Isnawati Tingginya Angka Cerai Gugat (Khulu') di Indonesia: Analisis Kritis Terhadap Penyebab dan Alternatif Solusi Mengatasinya, Al-'ADALAH Vol. XII, No. 1 Juni 2014, h. 203

Ra'd, Kamil Hayati. Memecahkan Perselisihan Keluarga Menurut Qur'an dan Sunnah. Yogyakarta: Mitra Pustaka, 2004.

R.Wirjono Prodjodikoro. Hukum Perkawinan di Indonesia. Jakarta: Sumur Badung, 1960.

Shinta Dewi, Sarafina. Pembentukan Undang-undang Nomor. 1 Tahun 1974 tentang Perkawinan. Jakarta: Pustaka Ilmu, 2011.

Soemiyati, Hukum Perkawinan Islam dan Undang-Undang Perkawinan. Yogyakarta: Liberty, 2007.

Wahyu, Ernaningsih dan Putu Samawati. Hukum Perkawinan Indonesia. Palembang: PT Rambang Palembang, 2008.

Undang-Undang Nomor 1 Tahun 1974 Tentang Perkawinan.

KHI (Kompilasi Hukum Islam) Hukum Perkawinan, Kewarisan, Perwakafan.

Putusan Pengadilan Jakarta Barat Mengenai Nafkah, Mut'ah, Harta Gono Gini , Tahun 2014-2015.

Putusan Mahkamah Agung tentang harta Gono Gini Tahun 2014-2015. 